\title{
New records of nocturnal Anomaloninae (Hymenoptera: Ichneumonidae) in South America
}

\author{
DANIELL R.R. FERNANDES ${ }^{1}$ and FRANCISCO A. DÍAZ ${ }^{2}$ \\ ${ }^{1}$ Programa de Pós-Graduação em Entomologia, Coordenação de Biodiversidade, Instituto Nacional de \\ Pesquisas da Amazônia, Av. André Araújo, 2936, Aleixo, 69067-375 Manaus, AM, Brazil \\ ${ }^{2}$ Universidad Centroccidental Lisandro Alvarado, 3001 Barquisimeto, Lara, Venezuela \\ Manuscript received on March 20, 2018; accepted for publication on June 21, 2018
}

\begin{abstract}
How to cite: FERNANDES DRR AND DÍAZ FA. 2019. New records of nocturnal Anomaloninae (Hymenoptera: Ichneumonidae) in South America. An Acad Bras Cienc 91: e20180291. DOI 10.1590/0001-3765201920180291.

Abstract: We report for the first time Aphanistes ruthae Alvarado, 2018 in Venezuela and Castrosion renei Gauld \& Bradshaw, 1997 in South America (Venezuela and Brazil). Castrosion renei is associated with the amazon rainforest in the Amazonas and Maranhão, States of Brazil.
\end{abstract}

Key words: Aphanistes, Amazon rainforest, Castrosion, Gravenhorstiini, neotropical region.

\section{INTRODUCTION}

The family Ichneumonidae (Hymenoptera: Ichneumonoidea) comprises parasitoid insects, some of which are used in biological pest control. It is one of the largest families among insects, comprising 60 to 100 thousand estimated species (Townes 1969, Gauld 2002). In Brazil, the ichneumonid fauna is represented by 225 genera and 947 species (Fernandes et al. 2018). However, this is certainly an underestimated number when it is being considered that Brazil is one of the most diverse countries of the world and its fauna still remains poorly studied.

The Anomaloninae (Hymenoptera: Ichneumonidae) are easily recognized by their delicate and elongated habitus, the absence of an areolet on the fore wing and the presence of a reticulate propodeum (Gauld 2006). The subfamily is divided into two tribes, Anomalonini Viereck,

Correspondence to: Daniell Rodrigo Rodrigues Fernandes

E-mail: daniellrodrigo@hotmail.com

ORCID: https://orcid.org/0000-0002-2208-6349
1918 and Gravenhorstiini Enderlein, 1912, which altogether have 45 genera (Yu et al. 2012, Sheng et al. 2012, Broad 2014).

There are 17 genera in the Neotropical region, but only eight genera and 24 species have been registered in Brazil and so far, neither of them has been formally registered in Venezuela (Yu et al. 2012, Fernandes et al. 2018).

Aphanistes Foerster, 1869 is a moderately large, widespread genus comprising 68 species, of which only 14 species occur in the Neotropical region (Yu et al. 2012, Alvarado 2018). Recently, Alvarado 2018 described five new nocturnal species from high mountainous areas of Ecuador and Peru, but currently, no species of this genus has been reported from Venezuela. Castrosion Gauld \& Bradshaw, 1997 is a monotypic genus described from Costa Rica, and it may be easily recognized by the larger size in comparison to other Anomaloninae, large ocelli and specific fore wing venation (Gauld and Bradshaw 1997). At this moment no species of this genus has been formally reported from South America. 


\section{MATERIALS AND METHODS}

This study was based on material deposited in the following institutions; names of curators given in parenthesis:

CZMA - Coleção Zoológica do Maranhão, Caxias, Maranhão, Brazil, (F. Limeira-de-Oliveira).

INBio - Instituto Nacional de Biodiversidad, Santo Domingo de Heredia, Costa Rica, (R. Zuñiga).

INPA - Coleção de Invertebrados do Instituto Nacional de Pesquisas da Amazônia, Manaus, Amazonas, Brazil, (M. L. Oliveira).

MJMO - Museo Entomológico “José Manuel Osorio", Universidad Centroccidental "Lisandro Alvarado" (formerly UCOB), Cabudare, Lara, Venezuela, (F. A. Diaz).

Observations were carried out using a Leica MZ 9.5 stereomicroscope under fluorescent light source. Photographs were taken using a Leica (M165C) stereomicroscope with a DFC420 digital camera and Leica Application Suite V3.4.1 (Version 2009). Series of partially focused digital images were stacked using the Helicon Focus software (Version 6.7) to produce final images with enhanced quality. For a more efficient light diffusion, a dome was used along with a tracing paper ring around the specimens (Kawada and Buffington 2016).

Species distributions were assembled in a dataset and incorporated into distribution maps. Geographic coordinates of the species records, if not present in labels, were taken from Google Earth software (https://www.google.com/earth/), and the map was generated using SimpleMappr (Shorthouse 2010).

\section{TAXONOMY}

Ichneumonidae Latreille, 1802

Anomaloninae Viereck, 1918

Gravenhorstiini Enderlein, 1912

Aphanistes Foerster, 1869

Aphanistes ruthae Alvarado, 2018
(Fig. 1).

Distribution: Venezuela (Trujillo and Portuguesa) and Peru (Cuzco and Pasco) (Fig. 2).

Host: unknown.

Material examined: 2 males. VENEZUELA, Trujillo: Parque Nacional Guaramacal, 1480m, 1420.II.2002, $09^{\circ} 19^{\prime} 02^{\prime}$ 'N-70¹5'48”W, mixed light trap, R. Briceño; A. Chacon; J. Clavijo; F. Diaz; R. Paz; L. Joly, Proyecto S1-2000000479, 1 male (MJMO); Portuguesa: Parque Nacional Guache, 9॰28’42”N-69³3'07’'W, light trap, X.2014, F. J. Sosa, 1 male (MJMO).

Alike Castrosion and others nocturnal ichneumonids, A. ruthae has an ophioniform habitus and all studied specimens were collected in light traps. The studied specimens were identified based on the original description (Alvarado 2018).

Castrosion Gauld \& Bradshaw, 1997

Castrosion renei Gauld \& Bradshaw, 1997

(Figs. 3 and 4).

Distribution: Costa Rica (Alajuela, Guanacaste, Heredia and Puntarenas), Venezuela (Lara and Barinas) and Brazil (Amazonas and Maranhão) (Fig. 2).

Host: unknown.

Material examined: 8 females and 3 males.COSTA RICA, Guanacaste: Bagaces, Parque Nacional Palo Verde, Stor Palo Verde. 10m. 14-17.VI.1999, I. Jiménez., light trap, L_N_260300_390150,

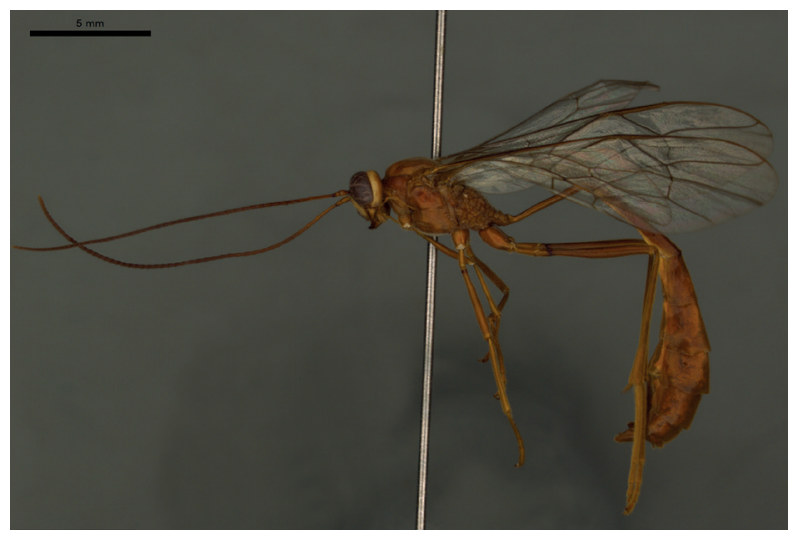

Figure 1 - Aphanistes ruthae Alvarado, 2018, male habitus. 


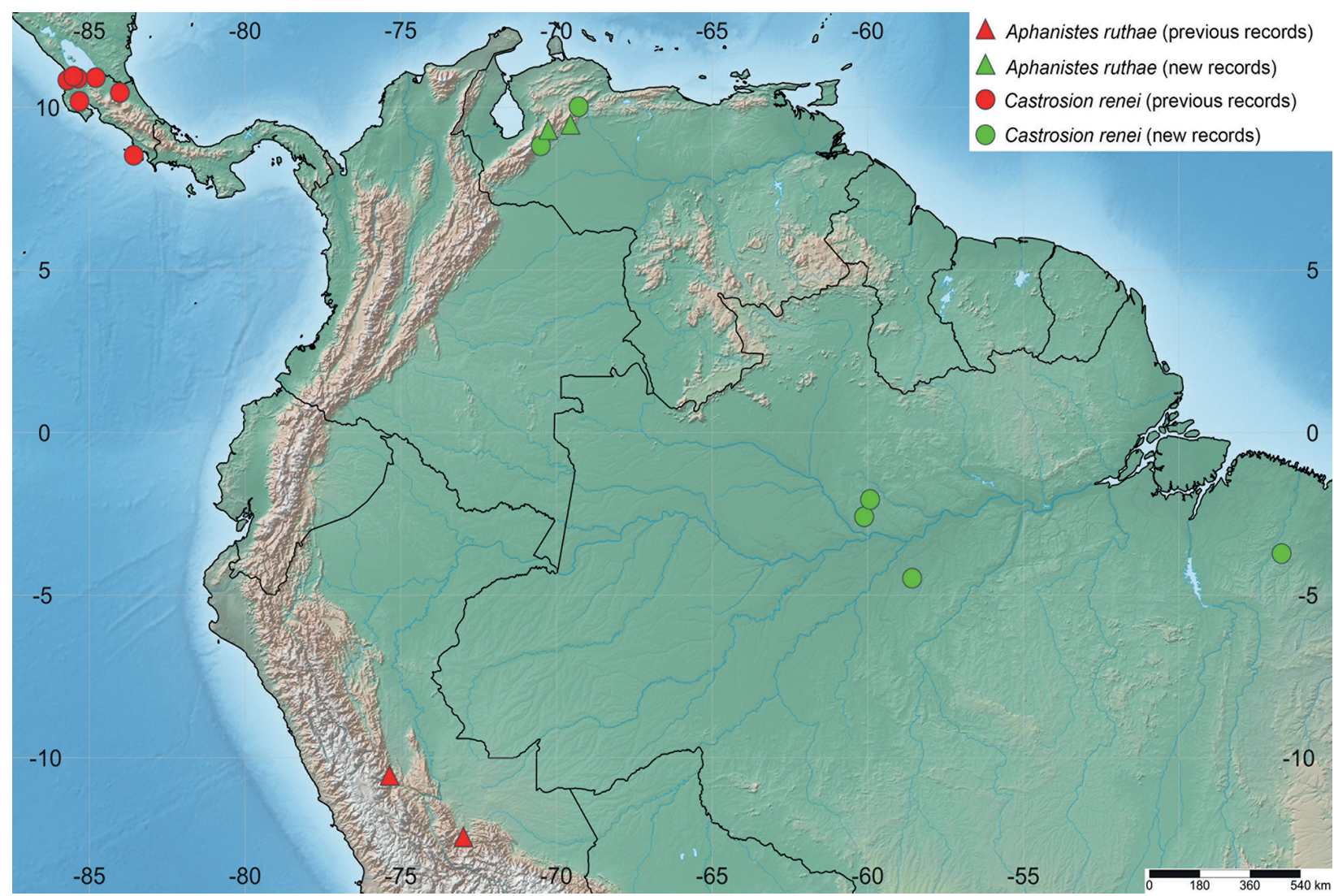

Figure 2 - Distribution records of Aphanistes ruthae Alvarado, 2018 and Castrosion renei Gauld \& Bradshaw, 1997.



Figure 3 - Castrosion renei Gauld \& Bradshaw, 1997, female habitus.

\#53666, 1 male (INB0003040939, INBio); Bagaces, Parque Nacional Palo Verde, Stor Palo Verde. 10m. 14-17.VI.1999, I. Jiménez., light trap, L_N_260300_390150, \#53666, 1 male (INB0003040940, INBio). VENEZUELA, Lara:

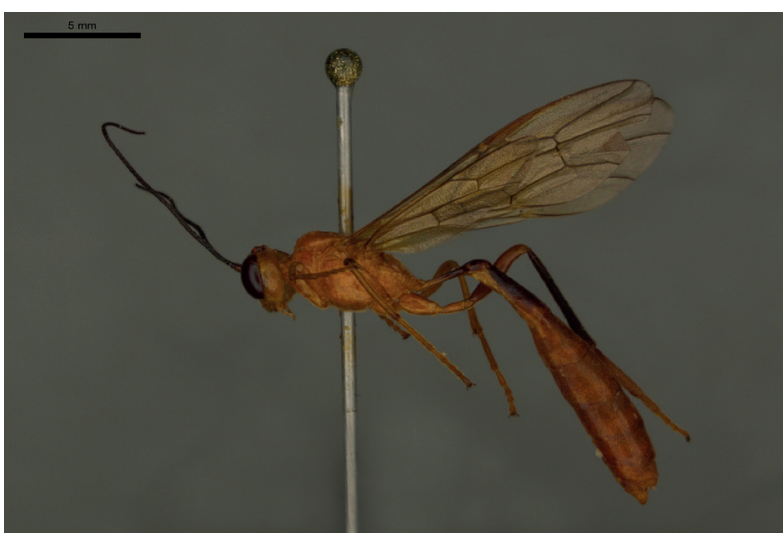

Figure 4 - Castrosion renei Gauld \& Bradshaw, 1997, male habitus.

Tarabana, 500m, 18.IV.91, col. A. J. Escalona, 1 female (MJMO); Barinas: Barinitas, via Barinitas, El Cacao, 25.V.1981, light trap, J. M. Osorio, C. Pereira, A. Escalona, 1 female (MJMO). BRAZIL, Amazonas: Manaus, ZF2, km14, Torre (35m), 
$02^{\circ} 35^{\prime} 21^{\prime \prime S} 60^{\circ} 065^{\prime}$ 'W, mixed light trap and BLB light trap, 13-16.VIII.2014, J. A. Rafael, F. F. Xavier Filho, A. R. Ururahy, A. Silva Filho \& S. Trovisco, 2 females (INPA); ZF2, Torre (40m), $02^{\circ} 35^{\prime} 21^{\prime}$ 'S $60^{\circ} 06$ '55”W, light trap, 26.X.2003, J. A. Rafael, F. F. Xavier Filho \& A. Silva Filho, 1 female (INPA); Borba, Rio Abacaxis, Paxiuba, $04^{\circ} 28^{\prime} 48^{\prime \prime} \mathrm{S} 58^{\circ} 34^{\prime} 24^{\prime \prime} \mathrm{W}$, light trap in a boat, 0204.VI.2008, J. A. Rafael e equipe, 1 female (INPA); Presidente Figueiredo, Estrada de Balbina km 12, Igarapé Santuário, 0203’36”S 5955’35”W, 1930.IX.2003, Xavier Filho, F. F. \& Vidal, J.M., 1 female (INPA); Maranhão: Bom Jardim, REBIO Reserva Biológica Gurupi, Mobile light trap, 1727.I.2010, F. Limeira-de-Oliveira, J. T. Câmara \& M. B. Aguiar Neto, 1 male and 1 female (CZMA).

Castrosion renei has an ophioniform habitus, such as Netelia Gray, 1860 (Tryphoninae) and Rhopalosoma Cresson, 1865 (Rhopalosomatidae), and alike them, is probably nocturnal (Gauld and Bradshaw 1997). All studied specimens were collected in light traps, which support this hypothesis. The studied specimens were identified based on the original description (Gauld and Bradshaw 1997).

The studied females show a variation in color of the posterior femur, a feature not recorded in original description, as well as a dark brown posterior tarsi in some specimens. One specimen from Borba in Amazonas possesses metasoma with tergites III to VII concolour with I and II (Fig. 5). In spite of this variation, as it was found in only one specimen, we consider it premature to treat it as a new species, although intermediate forms of this variation were not found.

This is the first record for Aphanistes species in Venezuela and Castrosion species in Venezuela and Brazil. In Brazil, C. renei is associated with the amazon rainforest of the Amazonas and Maranhão states.

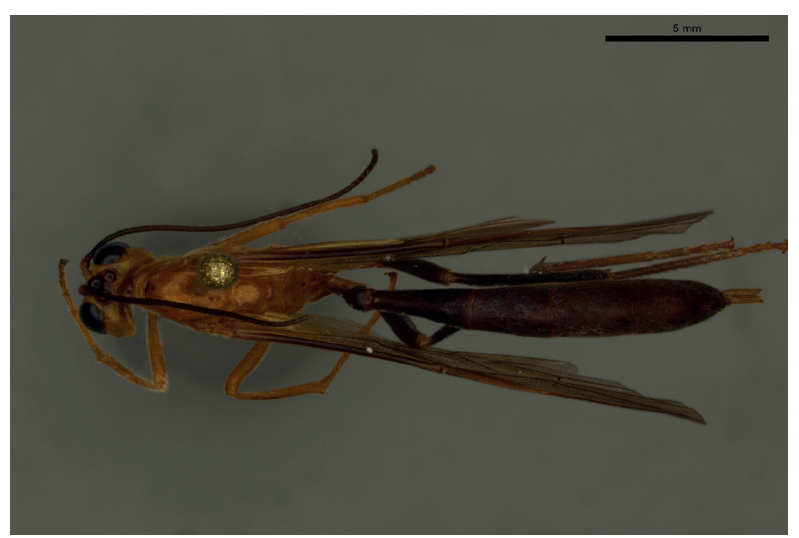

Figure 5 - Castrosion renei Gauld \& Bradshaw, 1997, female metasoma, dorsal view.

\section{ACKNOWLEDGMENTS}

We would like to thank Fundação de Amparo a Pesquisa do Estado do Amazonas (FAPEAM), Edital $n^{\circ}$ 030/2013 - Universal Amazonas (process $n^{\circ}$ 062.00770/2015); Pronex CNPq/FAPEAM project; CAPES ProEquipamentos; Dra. Neusa Hamada/Conselho Nacional de Desenvolvimento Científico e Tecnológico (CNPq) for logistic support. We also thank Ahana Maitra for english revision. This study was financed in part by the Coordenação de Aperfeiçoamento de Pessoal de Nível Superior (CAPES) Brasil - PNPD/CAPES.

\section{AUTHOR CONTRIBUTIONS}

DRRF and FAD identified the species, prepared the figures and wrote the manuscript.

\section{REFERENCES}

ALVARADO M. 2018. Nocturnal Aphanistes (Hymenoptera: Ichneumonidae: Anomaloninae) in the Neotropical region, with the description of five new species. Zootaxa 43: 221236.

BROAD GR. 2014. A new, endemic genus of Anomaloninae (Hymenoptera, Ichneumonidae) from St Helena. J Hym Res 41: 31-45.

FERNANDES DRR, SANTOS BF, PÁDUA DG AND ARAUJO RO. 2018. Ichneumonidae in Catálogo Taxonômico da Fauna do Brasil. PNUD. Available at: http://fauna.jbrj.gov.br/fauna/faunadobrasil/2248. Accessed on February 27, 2018. 
GAULD ID. 2002. Introduction. In: Gauld ID, Godoy C, Ugalde J and Sithole R (Eds), The Ichneumonidae of Costa Rica. Mem Am Entomol Inst 66: 1-768.

GAULD ID. 2006. Familia Ichneumonidae. In: Hanson PE and Gauld ID (Eds), Hymenoptera de la Región Neotropical. Mem Am Entomol Inst 77: 1-994.

GAULD ID AND BRADSHAW K. 1997. Subfamily Anomaloninae. In: Gauld ID, Wahl D, Bradshaw K, Hanson P and Ward S (Eds), The Ichneumonidae of Costa Rica. Mem Am Entomol Inst 57: 1-485.

KAWADA R AND BUFFINGTON ML. 2016. A scalable and modular dome illumination system for scientific microaphy on a budget. PLoS ONE 11(5): 1-20.
SHENG M-L, SCHÖNITZER K AND SUN SP. 2012. A new genus and species of Anomaloninae (Hymenoptera, Ichneumonidae) from China. J Hym Res 27: 37-45.

SHORTHOUSE DP. 2010. SimpleMappr, an online tool to produce publication-quality point maps. Available at: http://www.simplemappr.net. Accessed on April 22, 2017.

TOWNES H. 1969. The genera of Ichneumonidae. Mem Am Entomol Inst 11: 1-300.

YU DS, VAN ACHTERBERG C AND HORSTMANN K. 2012. Taxapad 2012, Ichneumonoidea 2011. Database on flashdrive. Available at: www.taxapad.com. 